
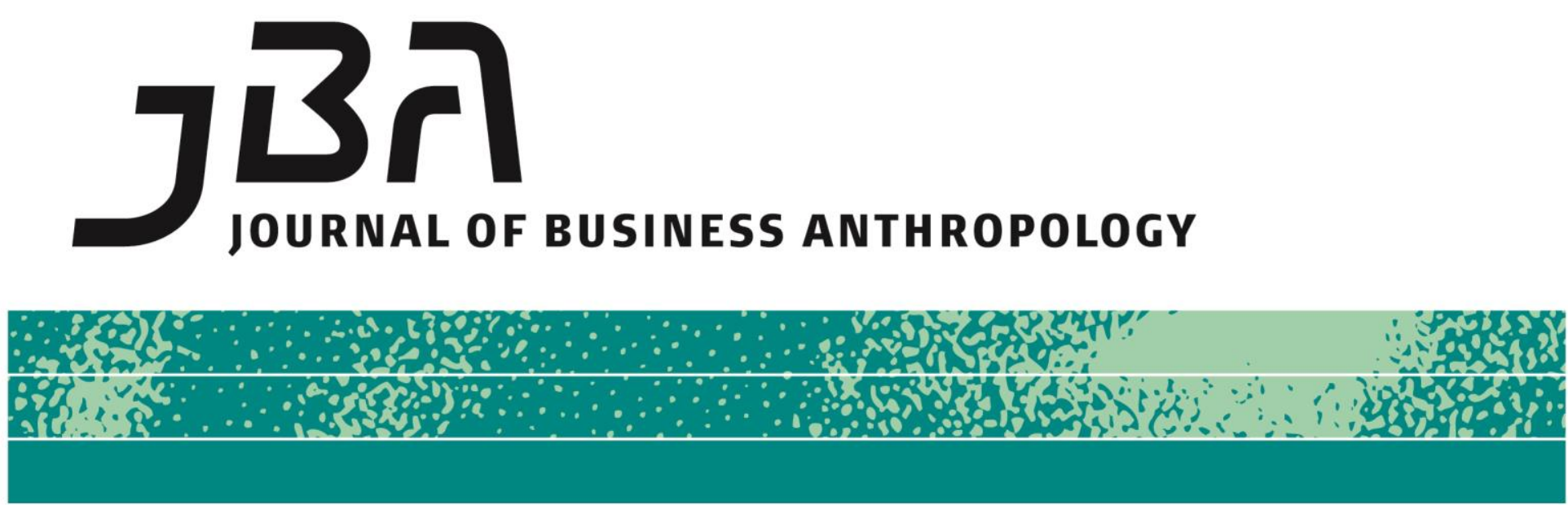

\title{
Essay
}

\section{Innovation: From the Forbidden to a Cliché}

\author{
Benoît Godin (Institut National de la Recherche Scientifique (INRS), \\ Montreal, Canada)
}

There are words and concepts-many words and concepts-that we use with no knowledge of their past. Such concepts are taken for granted and their meaning is rarely questioned. Innovation is such an anonymous concept.

Today, the concept of innovation is wedded to an economic ideology, so much that we forget that it has mainly been a political-and contested-concept for most of history. Before the twentieth century, innovation (and novation) was a vice, something explicitly forbidden by law and used as a linguistic weapon by the opponents of change. Innovation had nothing to do with creativity, not yet. The concept has a "negative history": a history of contestations, refutations, denigrations and denials. Innovation is something that the opponent of change or the conservative calls innovation. In contrast, today innovation is a word of honor. Everyone likes to be called an innovator; every firm innovates (or does it?); governments legislate to make whole nations innovative.

But how could people of the previous centuries constantly innovate but at the same time deny they innovate? In what follows, the paradox is best explained linguistically. Innovation is a bad word and
Page 1 of 9

JBA 4(2): 219-227 Fall 2015

(C) The Author(s) 2015 ISSN 2245-4217

www.cbs.dk/jba 
people prefer to cast their innovative behavior using other words. "Il fallait que l'innovation", claimed the French historian and intellectual Edgar Quintet, "s'accomplît sans que le génie du passé eût le moindre soupçon qu'il entrât quelque chose de nouveau dans le monde" [Innovation had to be carried out without the geniuses from previous times having the least suspicion that something new was being brought into the world] (Quintet, 1865: 208).

The concept of innovation changed meaning gradually over 200 years. Innovation acquired a positive connotation because of its instrumental function to political, social and material progress of societies. From the early nineteenth century, a whole vocabulary developed that tells a story to "create, even sanctify" a progressive future, rehabilitating dirty words until then-revolution-and adding new ones-creativity-to talk of and about innovation. From that time on, innovation became a catchword that everyone understood spontaneously, or thought he understood; that every theorist talked about; that every government espoused.

\section{Innovation and Order}

From its very emergence in Ancient Greece, the concept of innovation (kainotomia) had a political connotation. As "introducing change into the established order", innovation was subversive, or revolutionary, as we say today. This political and contested connotation was revived during the Reformation (see below). In the meantime, the concept made its entry into Latin vocabulary, with a positive meaning. From the fourth century, Latin writers, first of all Christian writers and poets, coined in-novo, which means renewing (return to the original or pure soul), in line with other Christian terms of the time-rebirth, regeneration, reformation-and according to the message of the New Testament (God sent his son Jesus to save man from sin). Innovo has no future connotation as such, although it brings a "new order." Innovo refers to the past: going back to purity or the original soul. The Vulgate was influential here. In 382, Pope Damasus I commissioned Saint Jerome to produce a "standard" version of the Vetus Latina, which he did using original Greek and Hebrew texts. Four books in the Vulgate make use of innovo in a spiritual context (Job, Lamentations, Psalms, Wisdom).

Innovation thus began with both a positive and negative meaning, but subsequently lost this valence when it moved to the politico-religious sphere of the Reformation. From the very beginning of the Reformation, royal and ecclesiastical authorities started using innovation in discourse. In 1548, Edward VI, King of England and successor to Henry VIII, issued a Proclamation Against Those That Doeth Innouate. The proclamation places innovation in context, constitutes an admonition not to innovate and imposes punishments on offenders: 
Considering nothing so muche, to tende to the disquieting of his realme, as diversitie of opinions, and varietie of Rites and Ceremonies, concerning Religion and worshippyng of almightie God ...; [considering] certain private Curates, Preachers, and other laye men, contrary to their bounden duties of obedience, both rashely attempte of their owne and singulet witte and mynde, in some Parishe Churches not onely to persuade the people, from the olde and customed Rites and Ceremonies, but also bryngeth in newe and strange orders ... according to their fantasies ... is an evident token of pride and arrogance, so it tendeth bothe to confusion and disorder ...: Wherefore his Majestie straightly chargeth and commandeth, that no maner persone, of what estate, order, or degree soever he be, of his private mynde, will or phantasie, do omitte, leave doune, change, alter or innovate any order, Rite or Ceremonie, commonly used and frequented in the Church of Englande ... Whosoever shall offende, contrary to this Proclamation, shall incure his highness indignation, and suffer imprisonment, and other grievous punishementes.

The proclamation is followed by the Book of Common Prayer, whose preface enjoins people not to meddle with the "folly" and "innovations and new-fangledness" of some men. A hundred years later, King Charles prohibited innovation again, and the Church produced lists of forbidden innovations, required bishops to visit parishes to enforce the ban, instructed bishops and archbishops as well as doctors (universities) and school-masters to take an oath against innovations and ordered trials to prosecute the "innovators." Advice books and treatises for princes and courtiers supported this understanding, and included instructions not to innovate. Books of manners urged people not to meddle with innovation. Speeches and sermons spoke against innovation, religious and political. Every opponent to innovation-puritans, ecclesiasts, royalists and pamphleteers-regularly repeated the admonitions of monarchs in support of their own case against innovators-until the second half of the nineteenth century in the case of religion.

The Reformation was a key moment in the history of the concept of innovation. At a time when the Reformation was incomplete and still in the making, the Catholics accused the reformers of innovating. The Puritans served the same argument to the Protestant Church, accused of bringing the Church back to Catholicism. The word served both sides of the debate: reformers and counter-reformers. It was precisely in the context of the Reformation that the concept entered everyday discourse.

This was only the beginning. Soon the meaning of innovation was 
to be enlarged. First, to the political; the monarchists of the seventeenth and eighteenth centuries accused the republicans of being "innovators". Innovation was revolutionary ... and violent. No republican-no citizen in fact, not even the most famous Protestant reformers or the French revolutionaries-thought of applying the concept to his own project. Innovation was too bad a word for this. In contrast, and precisely because the word was morally connoted, the monarchists used and abused the word and labelled the Republican as an innovator. This linguistic practice continued until the French Revolution-and later-and cast the idea of innovation into general disrepute: "Un préjugé général, produit par la haine de la révolution, a établi, avec des apparences assez favorables, que tout ce qui l'a immédiatement précédé, est excellent: c'est comme innovation qu'on la dénigre principalement; et par là même un discrédit général a dû s'attacher à toutes sortes d'innovations" [A general bias, arising from the hatred toward the revolution, established, with apparently considerable support, that everything immediately preceding it was excellent: it is as an innovation that is denigrated; and as a result every innovation has come to be discredited] (Montlosier, 1814, tome trois: 137).

\section{Frequency of the Term Innovation Over Time}

(Google Ngram)

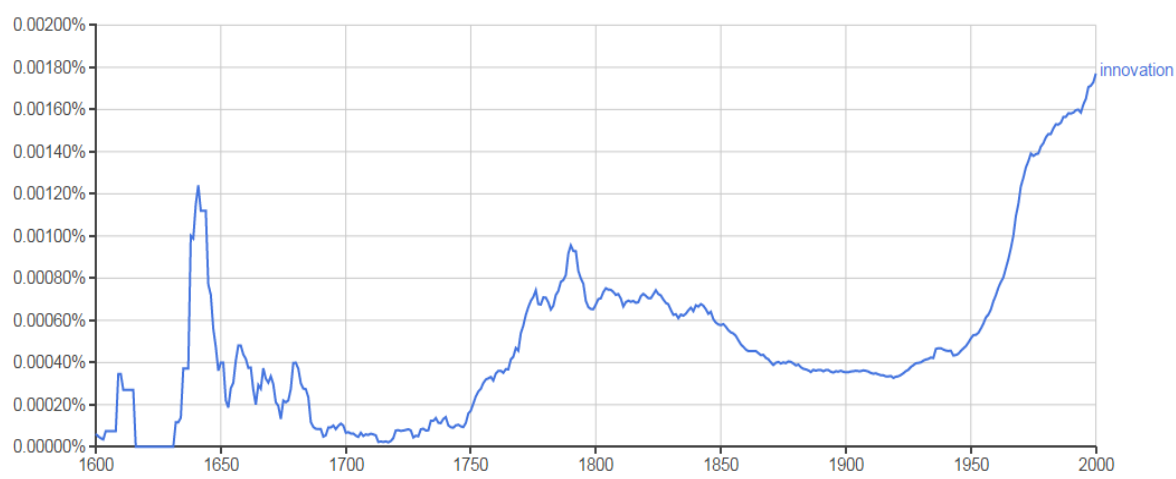

Secondly, innovation widened its meaning to the social. The social reformer or socialist of the nineteenth century was called a "social innovator," as William Sargant puts it in Social Innovators and Their Scheme (1858). His aim was to overthrow the social order, namely private property. Innovation was seen as a scheme or design in a pejorative sense, as it was a conspiracy in political literature (words used include project, plan, plot, or machination). This connotation remained in vocabulary until late in the nineteenth century, although some writers discussed social innovation using the positive idea of (social) reform. For example, in 1888, a popular edition of the Encyclopedia Britannica included a long article on communism which began as follows: "Communism is the name 
given to the schemes of social innovation which have for their starting point the attempted overthrow of the institution of private property."

Everyone shared this representation of innovation. Natural philosophers, from Francis Bacon onward, never referred to innovation as what is certainly the most innovative project in science: the experimental method. Equally, very few artisans and inventors talked of their invention in terms of innovation. Innovation was political.

\section{Innovation as an Instrument of Progress}

The concept of revolution and the concept of innovation changed meaning and started to be used in a positive sense at about the same time. The "spirit of innovation," a pejorative phrase of the previous centuries, became one of praise. This occurred gradually over the nineteenth century, particularly in France - "le centre de l'esprit philosophique et novateur" [the centre of philosophical and innovative spirit] (Littré, 1873: 208)-and got full hearing in the twentieth century. Two rehabilitations of the concept served this purpose. One was a semantic re-description: people start producing reflexive thoughts on what innovation was and concluded that the concept admitted of different interpretations. Innovation was neutral. There were good and bad innovations. Yet innovation was in fact a word of accusation, the "war cry of the fools", as Jean d'Alembert puts it in his Éloge de L'Abbé François Régnier Desmarais (1786). Yet, innovation might also be a good thing, namely useful.

Here lay a second rehabilitation, an instrumental one. Innovation was a means to political, social and material progress. Writers narrated or rather rewrote the story of the past in terms of innovation, including the Reformation and the Revolution and talk of innovators in superlative terms. Innovation was a source of national pride too:
L'Américain pris au hasard doit donc être un homme ardent dans ses désirs, entreprenant, aventureux, surtout novateur. Cet esprit se retrouve, en effet, dans toutes ses œuvres ; il l'introduit dans ses lois politiques, dans ses doctrines religieuses, dans ses théories d'économie sociale, dans son industrie privée ; il le porte partout avec lui, au fond des bois comme au sein des villes [The American must be fervent in his desires, enterprising, adventurous, and above all, innovative. This spirit can be found in everything he does: he introduces it into his political laws, his religious doctrines, his theories of social economy, and his private industry; it remains with him wherever he goes; be it in the middle of the woods or in the heart of cities] (Tocqueville, 1835 : 201).

Yet the transition from the negative to the positive was not sudden. One 
had to wait until the twentieth century for a complete reversal in the representation of innovation. This occurred after World War II. Those who contested innovation in the past-governments-started decontesting innovation and produced reflexive thoughts on innovation as a policy tool. One after the other, international organizations and governments began to embrace innovation as a solution to economic problems and international competitiveness, and then launched innovation policies. At that precise moment, the dominant representation of innovation shifted to that of the economy: technological innovation-a phrase that emerged after World War II-as commercialized invention. Technological innovation serves economic growth. A whole new set of arguments has developed: research and development (R\&D) leads to innovation and innovation to prosperity. Statistics are developed to support the idea: innovation surveys are administered to firms and the numbers collected into "innovation scoreboards" that serve as so-called evidence-based information for policy-makers. Innovation becomes a basic concept of economic policy. In a matter of decades, science policy shifted to technology policy and thence to innovation policy, and indicators of science and technology like R\&D have been relabeled indicators of innovation. In all these efforts, governments have been supported by academics as consultants, who produce models of innovation by the dozens, as a way to frame and guide policies. Model itself becomes an integral concept in the literature on innovation.

Ironically, these developments led to the transformation of the concept from a means to an end to an end in itself. Over the twentieth century, innovation has become quite a valuable buzzword, a magic word. Innovation is the panacea for every socioeconomic problem. One need not inquire into a society's problems. Innovation is the a priori solution.

\section{Theorizing Innovation}

Beginning in the 1940s, theoretical thoughts on innovation appeared and theories of innovation began to multiply afterwards. Psychological, sociological and economically-oriented theories followed one after the other. Two theoretical perspectives-the economic (technology) and policy perspectives-served a market ideology, and theorists rapidly got government hearing.

Here, innovation is no longer an individual affair but a collective process. To be sure, the twentieth century has its individual heroes: the entrepreneurs. Yet, entrepreneurs are only one part of the process of innovation: a total process as some call it, or a socioeconomic process. As Jack Morton, engineer and research director at Bell Laboratories, who brought the transistor from invention to market and who is the author of numerous articles and a book on innovation, suggests (Morton, 1968: 57): 
Innovation is not a single action but a total [my italics] process of interrelated parts. It is not just the discovery of new knowledge, not just the development of a new product, manufacturing technique, or service, nor the creation of a new market. Rather, it is all [my italics] these things: a process in which all of these creative acts, from research to service, are present, acting together in an integrated way toward a common goal.

Defining innovation as a process is a twentieth century "innovation." Herein lies a semantic "innovation," an "innovation" that has had a major impact on the contemporary understanding of innovation. Until then, innovation as a concept was either a substantive (something new) or a verb (introducing, adopting something new), an end or a means. Sometimes it was also discussed in terms of a faculty (combination, creativity), an attitude (radicalism), aptitude (skill), or quality (originality, departure, difference):

- Substantive: novelties (new ideas, behaviours, objects)

- Action: introducing (or bringing in) something new

- Process: a sequence of activities from generating ideas to their use in practice

From the mid-twentieth century, innovation has been studied as a "process," a sequential process in time. Innovation is not a thing or a single act, but a series of events or activities (called stages) with a purpose. The theorists have made themselves "innovative ideologists" here, to use historian Quentin Skinner's phrase. They have brought in a new definition of innovation in reaction to a new context. Innovation as a process has contributed to giving the concept of innovation a very large function: innovation encompasses every dimension of an invention, from generation (initiation) to diffusion. For sociologists, the process is one from (individual) adoption to (social) diffusion; for economists, from invention to commercialization; for management schools, from (product) development to manufacturing. Everywhere, this process is framed in terms of a sequence (with stages) called models.

\section{Conclusion}

As the nineteenth century ended, the word innovation had accumulated four characteristics that made of it a powerful (and pejorative) term. From the Greeks, the representation of innovation had retained its subversive (revolutionary) character. The Reformation added a heretical dimension (individual liberty), and the Renaissance a violent overtone. Together, these characteristics led to a fourth one: innovation as conspiracy (designs, schemes, plots). Yet, in spite of these connotations that made a word (innovation) part of the vocabulary and discourses, innovation seems to have escaped the attention of intellectual or 
conceptual historians. Many concepts of change (crisis, revolution, progress, modernity) have been studied in literature, but innovation has not. Is innovation only a word-a mere word-in the vocabulary of adherents to the status quo-Churches, Kings and their supporters-and devoid of sociological meaning?

In a certain sense, it is. Before the twentieth century, no theory of innovation existed. Innovation was a concept of limited theoretical content, a linguistic weapon used against one's enemy. In another sense, innovation was not devoid of sociological meaning. The opponents of innovation in the seventeenth and eighteenth centuries provided the first image of innovation and innovators, one that lasted for centuries. What constituted innovation and who was an innovator were defined by the enemies of innovation and innovators. It is against this pejorative image or representation that innovators had to struggle in the nineteenth century, when they started making use of the concept in a positive sense. The case of innovation is one more instance of the influence of religion on modern secular thought.

Before the twentieth century, the idea of innovation belonged to experience, but very rarely to thoughts and dreams. The innovator himself made no use of the word. As Reinhart Koselleck puts it on deeds, for centuries it was not innovation itself that shocked humanity but the word describing it (Koselleck, 1972). The novelty (the "innovation") of the twentieth century was to enrich the idea of innovation with thought, dreams and imagination. Innovation took on a positive meaning that had been missing until then, and became an obsession.

The changing fortune of innovation over the centuries sheds light on the values of a particular time period. In the seventeenth and eighteenth centuries, the uses of the concept were essentially polemical. It served as a linguistic weapon, attaching a pejorative label to the innovators. In contrast, from the nineteenth century onward, innovation started to refer to a central value of modern times: progress and utility. As a consequence, many people started appropriating the concept for their own ends. Yet, there is danger here that a word, as a "rallying-cry," may become "semantically null." "Terms of abuse cease to be language" (Lewis, 1960: 328). As Pocock puts it with regard to the word revolution: "the term [innovation] may soon cease to be current, emptied of all meaning by constant overuse" (Pocock, 1971: 3).

\section{References}

Alembert, Jean le Rond d' (1786), Histoire des membres de l'Académie française, morts depuis 1700 jusqu'en 1771, pour servir de suite aux éloges imprimés \& lus dans les Séances publiques de cette Compagnie, tome 3, Amsterdam: Moutard. 
Koselleck, Reinhart (1972), "Begriffsgeschichte and Social History," in R. Koselleck (ed.), Futures Past: On the Semantics of Historical Time, New York: Columbia University Press, 2004: 75-92.

Lewis, Clive Staples (1960), Studies in Words, Cambridge: Cambridge University Press, 1967.

Littré, Émile (1873), La science au point de vue philosophique, Paris Didier et Cie.

Montlosier, François Dominique de Reynaud de (1814), De la monarchie française, depuis son établissement jusqu'à nos jours; ou recherches sur les anciennes institutions françaises, leur progrès, leur décadence, et sur les causes qui ont amené la révolution et ses diverses phases jusqu'à la déclaration d'empire; avec un supplément sur le gouvernement de Buonaparte, depuis ses comencemens jusqu'à sa chute; et sur le retour de la maison de Bourbon, three volumes, Paris: H. Nicolle/A. Édron/Gide fils.

Morton, Jack A. (1968), “The Innovation of Innovation," IEEE Transactions on Engineering Management, EM-15 (2): 57-65.

Pocock, John G. A. (1971), "Languages and Their Implications: The Transformation of the Study of Political Thought," in Politics, Languages and Time: Essays on Political Thoughts and History, Chicago, University of Chicago Press (1989): 3-41.

Quinet, Edgar (1865), La Révolution, Paris: Félix Alcan, 1891.

Tocqueville, Alexis de (1835), De la démocratie en Amérique I, Paris: Gallimard, 1992.

Benjoît Godin is professor, INRS, Montral (QUE), Canada. For many years, he has worked on the history of statistics in science and, in 2005, published Measurement of Science and Technology : 1920 to the Present (Routledge). At present, he is conducting research on the cultural and conceptual history of innovation. His latest book is Innovation Contested: The Idea of Innovation over the Centuries (also Routledge, 2015). He may be reached at benoit.godin@ucs.inrs.ca. 